\title{
Humanity's perceived right to life and the impact thereof on the environment: A perspective from Deuteronomy 20:19-20
}

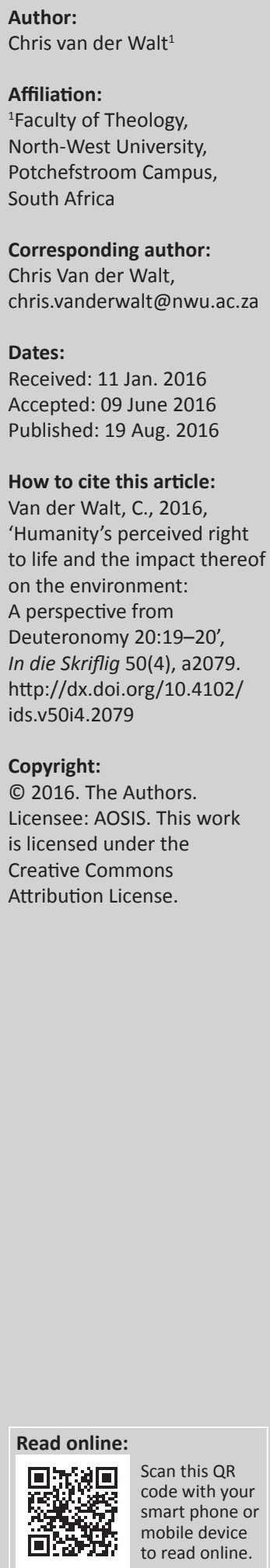

\begin{abstract}
Humanity's day to day activities are currently impacting on the natural environment in a way unknown before. Although the destruction of natural resources in times of war is prohibited by the Geneva Conventions, it is currently also happening during periods of peace. The reason for this is the undisputed right to life that humans appropriate themselves regardless of the impact of their acts on the environment. According to Deuteronomy 20 all human life is not of equal value and not necessarily superior to life in nature. Deuteronomy 20 challenges conventional thinking on the subject of human-nature relationships. It is also challenged in Jewish Halachic thinking, the practicality of primitive Eskimo's attitude towards life and nature, as well as Assyrian acts during war. In these societies the dependence of humans on nature in order to ensure survival, was acknowledged. Currently a paradigm shift away from the anthropocentric attitude towards nature is needed to accommodate the conviction that functionality and potentiality should form part of our philosophy concerning the right to life. A new set of moral rules should be established, taking into account the fact that an endeavour to prolong human life indefinitely should not be desirable because it is to the detriment of nature and thus to humanity itself.
\end{abstract}

\section{Introduction}

Humanity's day to day activities are currently having a detrimental impact on our natural environment in a way unrivalled in history and it is evident that the impact will not lessen. The reason for this idea is expressed in the Daily Mail:

The first person who will live to see their 150th birthday has already been born. Aubrey De Grey believes that the first person to live for 1000 years will be born in the next two decades. (Doughty 2013)

Contrary to this, Sir David Attenborough warns: 'Humans are a plague on the Earth that need to be controlled by limiting population growth' (Gray 2013).

The above-mentioned contradictory viewpoints, need serious contemplation. On the one hand there is the human wish to prolong life almost indefinitely but on the other hand a well-known environmentalist warns that humans are a plague on earth. In customary reasoning every endeavour will be made to eradicate plagues because of the threat it holds. In the case of humans, eradication is not an option, for various reasons. The situation cannot, however, just be left to its own accord because of the detrimental effect human activities have on the natural environment of which we form part of.

Although 'nature' is generally envisioned by humans as a pristine, almost paradisiacal environment, the current reality is far from that. In recent newspaper articles, even the oceans are increasingly described as 'a plastic soup' (Milman 2014).

The reason for this is the right to life that humans claim for themselves, regardless of the massive impact we have on the ecology of the earth.

From time to time events and issues in our society make us more sensitive to some biblical texts than others and Deuteronomy 20 is such a case. Deuteronomy has a different view from normal thinking as will be argued in this article.

\section{Humanity's perceived right to life and its effect on the environment}

The conventional view of man's right to life can be found in the proceedings of the Centre for Research and Study in International Law and International Relations of the Hague Academy of 
International Law of 1983. In the proceedings, which were recorded as essays, Gormley states:

The underlying international public order will impose a higher obligation in regard to the right of life, because of the fact that the inherent value of the right to life is recognized by the global community. (Gormley 1985:147)

This statement focuses the attention on the perceived moral principle based on the belief that a human being has the right to live because he and/or she is alive. It is against this background that the view that man will soon live to the age of a 1000 years, can be seen. As far as the average human mind is concerned, it is envisaged that the environment on earth will graciously tolerate an uncontrolled expansion of the human population. This view is further reiterated by other statements from the above-mentioned publication, namely, that of Ramcharan (1985:1) who said: 'The human factor is emerging, at last, as the factor which should govern in every situation'.

Reiterating the outright priority that human life has, Gormley adds the notion of jus cogens which refers to certain fundamental, overriding principles of international law, from which no derogation is ever permitted:

Specifically, jus cogens applies to those rights the violation of which threatens all of mankind and the very existence of the international community. Mass and gross violations (e.g. apartheid, war crimes, slavery, etc.) as discussed in this study will continue to endanger man's survival on this planet. (Gormley 1985:148)

In the light of these jurisdictive perspectives on the right to human life, there is another more pressing aspect which can be added to those that Gormley mentioned. It literally threatens every human being the international community comprise of and it is the reality sketched in the findings of the Living Planet Report of 2014:

The Living Planet Index (LPI), which measures more than 10,000 representative populations of mammals, birds, reptiles, amphibians and fish, has declined by 52 per cent since 1970. Put another way, in less than two human generations, population sizes of vertebrate species have dropped by half. These are the living forms that constitute the fabric of the ecosystems which sustain life on Earth - and the barometer of what we are doing to our own planet, our only home. We ignore their decline at our peril. (World Wildlife Fund [WWF] 2014:4)

It is thus not just the violation of human rights by other humans that is endangering man's survival on this planet but also man's violation of the natural environment on a global scale. What makes this of special importance is that apartheid, war crimes and slavery (detestable as they are) do not endanger all humans on the planet, but violation of the natural environment does.

\section{International law and the environment}

The situation reported by the Living Planet Report of 2014 developed although certain measures to protect the environment had already been put in place, one of which is Additional Protocol I to the Geneva Conventions of 12 August 1949 (International Committee of the Red Cross [ICRC] 1977). Additional Protocol I was the first to provide direct protection to the environment in times of war and the following quoted articles from the protocol are of importance.

\section{Article 35}

It is prohibited to employ methods or means of warfare which are intended, or may be expected, to cause widespread, long-term and severe damage to the natural environment.

\section{Article 54}

Starvation of civilians as a method of warfare is prohibited.

It is prohibited to attack, destroy, remove or render useless objects indispensable to the survival of the civilian population, such as foodstuffs, agricultural areas for the production of foodstuffs, crops whether in order to starve out civilians, to cause them to move away, or for any other motive.

\section{Article 55}

Care shall be taken in warfare to protect the natural environment against widespread, long-term and severe damage. Attacks against the natural environment by way of reprisals are prohibited.

All things considered, the operative core of these provisions is the triple and cumulative standard of 'widespread', 'longterm' and 'severe'. Reality of war led to an article published in the Nordic Journal of International Law which constructively addressed the subject of environmental protection during armed conflict as ruled by the United Nations Environment Programme (UNEP). In the article Thomas put forward certain suggestions in order to help establish the content and scope of the obligation to protect the environment with relation to armed conflict in customary international law. In his conclusion he made the following remark:

Finally, it must be asked, what is the most effective way to inculcate environmental protection into strategic considerations and thus into the culture of military decision-making? As the author of Deuteronomy understood long ago, arguments for environmental regard and against wanton destruction must acknowledge military realities without sacrificing legal or ethical clarity. (Thomas 2013:101)

What makes the situation complicated is that military action can be ruled by the international community and steps can be taken against perpetrators for violating the rules of the UNEP. The burning question is, however, what to do when the human community's day to day activities and not war are responsible for destruction to the extent that it can be classified as 'widespread', 'long-term' and 'severe'?

It has become necessary to acquire wisdom to come to grips with the thinking processes which lead to this kind of destruction. This wisdom can indeed be found in 
Deuteronomy because it deals with comparable situations of validation of human life and that of the environment in times of war, but also when there is peace.

\section{Approaching Deuteronomy 20}

In this article Deuteronomy 20:19,20 will be used to provide a theological interpretation in order to shed light on humans' perceived right to life and mankind's attitude towards nature.

Before I start with the discussion on Deuteronomy note must be taken of the following. The subject under discussion concerns our conscience which is shaped in a way that is not always consistent. Explained at the hand of Verbaan (2011) it can be understood according to the three-fold concept of index, vindex, iudex. Firstly there is the norm. You shall not murder which means you shall not take somebody else's life. That is the index. Then comes the vindex, the advocate who tells you that under certain conditions as in times of war, it is acceptable to take someone's life. Then there is the iudex, the judge who askes the question if it is really justifiable to take a life; or not to have taken a life? Evaluated according to this three-fold view the vindex and iudex will be derived from Deuteronomy 20:1-20. This chapter in the Pentateuch is approached by scholars from a number of vantage points as is indicated underneath:

- Arguing the formation of the text as being part of the Ancient Near Eastern literature and the manner in which wisdom teaching influenced the manner in which war was waged (Wright 2008).

- Arguing the composition, structure and subject matter of the text (Rofé 2002).

- Attempting to solve the puzzle of the text on a linguistic level (Barr 2003).

- Explaining it as understood by the Jewish rabbis which gave rise to its halachic precept of bal tashchit (Wolff 2009).

- Using it as point of departure to establish international law by the United Nations (Thomas 2013).

More angles could be identified by scholars interested in their own specific fields of research, which in turn will lead to conclusions related to those fields of research. The purpose of this article is to derive guidelines from Deuteronomy 20 that can induce evaluation of humankind's position on the following two aspects: the perceived right to life, and the underlying thoughts which result in behaviour towards the immediate environment of the global village in which all creatures on earth live in.

Deuteronomy is part of the Torah of which the purpose is to teach humans how to live wisely, also with regard to the environment (e.g. Dt 22:6, 7). The fact that the laws of Deuteronomy 20 were given in order for Israel to gain wisdom and make better choices in their conduct towards the environment, will help with the necessary reflection.

\section{Overview of Deuteronomy 20}

The passage under discussion forms part of the Deuteronomic code which begins in chapter 12 and stretches until 26, framing the legal material in Deuteronomy 13-25. As subsection of the legal material, chapter 20 deals with requirements of conduct during Yahweh's wars that Israel fought in order to take hold of the promised land (Lundbom 2013:77, 80).

The text of Deuteronomy is heavily influenced by the standard Hittite treaty texts which consisted of:

- The preamble.

- Historical prologue regarding the relationship of the parties involved.

- General stipulations that obligate the treaty partners.

- Specific stipulations.

- Lists of blessings and curses with regard to fulfilment or violation of the treaty.

- Witnesses (Barrett 2009:35).

For the argument of this article the text of Deuteronomy is thus regarded as a legal document which calls for attention in establishing judicial philosophy about human life.

\section{The text of Deuteronomy 20:19-20}

Barr wrote an article about the passage under discussion and aptly titled it: 'A puzzle in Deuteronomy' (Barr 2003:23). In this article he pointed out the difficulties involved in the text and the translation of the text. In his closing remark he did not lay claim to solving the problem of translating the text but merely considered it to be a contribution to the scientific conversation. The conversation about translation possibilities of Deuteronomy 20:19 is on-going and as a point of reference the translation of 20:19-20 from the English Standard Version (ESV) is given:

${ }^{19}$ When you besiege a city for a long time, making war against
it in order to take it, you shall not destroy its trees by wielding
an axe against them. You may eat from them, but you shall not
cut them down. Are the trees in the field human, that they
should be besieged by you? ${ }^{20}$ Only the trees that you know are
not trees for food you may destroy and cut down, that you may
build siegeworks against the city that makes war with you,
until it falls.

Lundbom (2013:589) gives a similar translation of the difficult

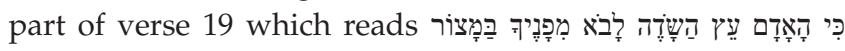
namely: '... for is the man the tree of the field coming before you in the siege?' This translation is motivated from the viewpoint of the LXX where ị is translated with $\mu$ m and thus taken as a rhetorical question to which a negative answer is expected. As far as the Hebrew text is concerned the qames under the $\pi$ is changed to a seghol which makes it a question. The understanding is then that the trees can be left standing because they do not pose a threat to the warriors.

The result of the above-mentioned translations is that no link of hostility between man and fruit trees exists. The only link is that of the provision of food and thus dependence. Therefore the trees should not be seen as objects against which war should be waged. 
There are, however, translations that link man and trees. This was done by Ibn Ezra (1089 to 1164 AD) and followed by the King James Version which translates the phrase as: '(for the tree of the field is man's life) to employ them in the siege:' The reasoning behind this understanding does not take the LXX reading into account but only the Masoretic text where כִ is understood as a marker of emphasis strengthening a statement and not as introducing a rhetorical question. According to Wolff (2011:147) the majority of Jewish commentators support this interpretation.

Irrespective of how the passage is translated and understood it cannot be denied that there is a causal relationship between humans and fruit trees. Even when no direct link between trees and humans is acknowledged, as is portrayed in the LXX orientated translation of verse 19, verse 20 clarifies the matter.

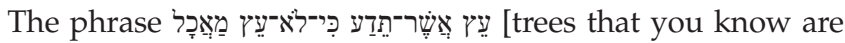
not trees for food] establishes a direct link between the fruit trees and sustainable nourishment. Interpreted in this way, humans still have a responsibility towards the fruit trees because of their dependence on the tree. Schwartz (1997:358) is therefore correct when he states that the main point is that trees provide fruit and should therefore not be cut down. From the above it can be inferred that fruit trees need to be protected and put to use irrespective of how the relationship between man and fruit trees is perceived.

With regard to this Brueggemann (2001) makes the following comment:

The purpose is to protect the food chain, even leaving a food supply for one's enemies after the battle when Israel's troops have withdrawn. Such a provision may be subsumed under an inchoate creation theology in which it is recognized that the created world has its own rights and privileges, and there are important limitations imposed on human intervention. (p. 213)

If Brueggemann is understood correctly it will mean that a degree of dissociation is established between humanity and creation because of creation's own rights. If the structure of the chapter is studied in depth, another conclusion can also be made which does not only point in the direction of limitation because of rights but also in the direction of interdependent functionality.

\section{Structure and purpose of Deuteronomy 20}

It is well known that the exposition of the laws in Deuteronomy 12-26 follows the order of the Decalogue. All the commands are elaborated on in these chapters, but special emphasis is placed on the explanation and application of the sixth commandment prohibiting murder. Preservation of life is thus on the foreground whether it is linked to moving a landmark and thus inhibiting sufficient food production because of impairment of land use, or falsely accusing someone of an offense which carries the death penalty (Wenham 2003:137). It is therefore not surprising to find the same kind of reasoning in chapter 20 which deals entirely with conduct during war.
The chapter can be divided into three main parts:

- 20:1-9: Soldiers' suitability for war and their mental preparation by the priests.

- 20:10-18: Strategy for combat against cities (subdivided into prescriptions for conduct towards enemy cities far off (10-15) and enemy cities which are near (16-18).

- 20:19-20: The environmental impact during a siege.

Approached from another perspective the chapter can be outlined thematically as follows: The opening section underlying the rest of the chapter: Don't be afraid when preparing for battle as God is with you (20:1-4).

Due to the threat of dying in war, provision for continuity is made regarding:

- The new home owner (20:5).

- Enjoyment of the fruit of the vineyard (20:6).

- Marriage (20:7).

- The man in fear lest he endangers the other soldiers (20:8).

- The city of the enemy by firstly offering peace (20:10-11).

- Some of those far away in order for Israel to physically survive (20:12-15).

- Israel's spiritual survival in the face of idolatry where no one who could endanger their spiritual survival should be given the chance to let them stray (20:16-18).

- Nature's continued existence (20:19-20).

Narrowing it down to the subject under discussion, 20:10-20 should not be seen as mandatory military tactics to be followed to the letter but rather as legal instruction during military action regarding cities in the Promised Land. The cities and what they contained were not to be considered as inherently evil and summarily destroyed but rather valued according to its worth. According to its value it should be established what degree of destruction should be applied, keeping in mind what value the remainder will have in the worship of Yahweh (Benjamin 1983:196). 'Value' was thus the principle according to which things were judged concerning whether it should be destroyed or saved. What was saved had to be put to use; whether it was people, animals, trees or vegetation.

Deuteronomy 20:10-20 therefore does not involve 'urbicide' as a ritualistic process of destroying the memory and identity of a city as triumph to some ruler (Wright 2015:161), but rather wisdom on the functional use of cities in memory of Yahweh who put it to the disposal of his people.

Destruction and violence should therefore not be seen as the focus in chapter 20, as is often the case, but conservation and prolonged life for nature and humanity should rather receive the emphasis. A valuation of the functionality of what ought to be kept intact after a siege is therefore needed, whether it be human life or natural resources. Read like this, it becomes clear that in the context of Deuteronomy 20 not all forms of life can be considered equally functional, not even all human life.

This conviction becomes evident from the following quoted passages in the ESV: 
- 20:10-11: When you draw near to a city to fight against it, offer terms of peace to it. And if it responds to you peaceably and it opens to you, then all the people who are found in it shall do forced labour for you and shall serve you.

- 20:12-14: But if it makes no peace with you, but makes war against you, then you shall besiege it. And when the LORD your God gives it into your hand, you shall put all its males to the sword, but the women and the little ones, the livestock, and everything else in the city, all its spoil, you shall take as plunder for yourselves.

The allowance that they could take it for themselves must be seen as a gift from God to whom everything belongs (Nelson 2002:248).

Contrary to the notion of jus cogens, which calls for no exception to the rule, irrespective of circumstances, Deuteronomy 20:10-14, as vindex, prescribes conduct towards people circumstantially and according to a certain context. The context of the wars portrayed in Deuteronomy 20 was not just that of חרם although complete destruction is commanded in 20:17. It is evident that the 'rule' was not applicable to all kinds of war (Zehnder 2013:271).

The rationale of destruction, or not, depended on the contribution a specific modality could make towards the quality of the community's life at large, or how it would hinder the quality of life in the presence of Yahweh. The whole chapter in fact deals with contribution and hindrance. If circumstances required service elsewhere, certain individuals need not contribute to war (20:5-8). When in war a formula of

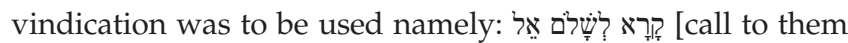
peace] (Jonker 1997:971). When this vindication was accepted, no further action was needed except putting the inhabitants to service/making them contribute towards the quality of life for Israel. If vindication was not accepted, war and siege should follow and after success only the object of enmity, namely the males were to be put to the sword thus neutralising the origin of military action (Rofé 2002:156).

Value was thus the principle measurement for what was to remain or destroyed. What was to remain was put to functional use in order to make a contribution to the society whether it was people to be used as labour or trees as sustenance. This can be derived from the use of the root אכל in Deuteronomy 20 verses 14 and 19 which is a marker of utilisation by the people of God.

The conviction that some humans were to be saved and others not, is not a norm in modern thinking. Nowadays every effort is made to prolong every human life even at the cost of other human lives and the environment. Deuteronomy 20 reflects a different stance.

As all humans were not assessed to be of equal functionality, all trees were also not assessed as equal. Verse 20 allows for trees that do not produce food to be cut down to be used as timber for siegeworks. This follows the same pattern as previously mentioned in the chapter where all people are not treated equally, with some to be devoted to God by complete destruction (חרם) while others were to be put to functional use.

Biblical thought about 'the right' to life is thus not dictated by the precept of 'a human being alive' and therefore having the right for indefinite preservation of his/her life at all cost, but by the functionality of human life. Human life should thus be pondered on from a practical vantage point as can be found in the Halachic precept of bal tashchit [do not destroy] which will be briefly discussed.

\section{Practical thinking: The Halachic precept of bal tashchit.}

In rabbinic Judaism the body of teachings pertaining direct practical application is referred to as [ִלָכָה [that by which one walks]. Halachah, then, is the 'way' a Jew is directed to behave in every aspect of life, encompassing civil, criminal, and religious law. The halachah extends beyond that which is forbidden and dictates normative behaviour.

As part of Halachic thinking, the prohibition of bal tashhit is arguably the most important religious precept directly relating to man's relationship with the environment. Deuteronomy 20:19,20 introduces the prohibition of bal tash it in the seemingly narrow context of preserving fruitproducing trees during a wartime siege (Wolff 2011:143).

Amongst the rabbis, no consensus could be found on the exact meaning of the central point of 'needless' or 'wanton' destruction. In extensive research by Schwartz different angles of approach were evaluated. The main question is as to whether needless destruction should be evaluated according to the effective use of the environment by human beings or whether nature does have an inherent value apart from human utilisation and need to be balanced alongside human wants and needs (Schwartz 1997:363). He summarised the different approaches under the following headings.

\section{Minimalist application}

The value of the one person cannot be put before the value of all. If one harms him/herself he/she is not punishable in civil law, but if his/her destruction harms all, he/she can be held liable.

Human considerations always determine the conduct toward nature.

\section{Maximalist application}

In this tradition, a degree of inherent worth is given to the natural world, independent of human consumption. This approach demands a much more complex negotiation between human wants and needs on the one hand and nature on the other.

The research carried out by Schwartz provides a view from another cultural perspective and is to be a meaningful stepping stone in the rethinking of our perspectives 
(Schwartz 1997:371-374). We should recognise the limitations of our culture-bound understanding of nature and the resulting impact we have upon it.

On this subject Wolff (2009) argues as follows:

It is very significant, in my opinion, that the Biblical prohibition of bal tashchit is taught with the example of fruit-producing trees, which symbolize the life support system - the natural resources and natural processes that provide for man's existence in this world. Therefore, the prohibition against the destruction of fruit-producing trees can be, and indeed has been interpreted in the Jewish tradition to include all resources - all useful materials and objects that are beneficial to man's existence. (p. 24)

In accordance with my own reasoning on Deuteronomy 20:10-20 bal tashchit also does not consider the value of all persons as equal and the maximalist application affords nature a value of its own; irrespective of human consumption.

Bal tashchit is derived from a religious vantage point, but with practicality in mind. For a non-religious and downright practical approach to the relationship between nature and humans and the materials and objects needed to survive in it, the perspective of the primitive Eskimos will be given next.

\section{Eskimo approach to nature and self-preservation}

It is general knowledge that primitive Eskimos lived in a very difficult natural environment and that their indigenous culture exemplified ingenious devices for meeting the demands of their physical environment. Hoebel (1941:665) described the laws of a primitive group called the Eskimo, in which their attitude to human life within their environment is portrayed. In this environment, sharing and economic cooperation are the supreme virtues, given the harsh environmental circumstances they had to survive in. As far as property is concerned the perspective is given that someone is permitted to accumulate property only for as long as he can be considered a public benefactor. This means that what he has gained is still available to some extent to the community at large. If this does not apply any more, that individual will be removed from the community (1941:667).

The ultimate act of self-preservation of the Eskimo people became apparent in the manner in which members of the community were allowed to survive. All of the undermentioned practices are, in whole or in part, responses to the basic principle of Eskimo society that only those who are able (or potentially able) to contribute actively to the subsistence economy of the community, may live. The primitive Eskimos, for example, recognised several forms of homicide as legally acceptable which modern law would define as murder, namely, infanticide, invalidicide, senilicide and suicide. The deciding factors are whether present resources were sufficient to nourish a member through non-productivity in the community (1941:670).

What is perhaps of the greatest importance for this article is the perspective and attitude the elderly amongst the Eskimos had about unconditional prolongation of life. This becomes evident in the following remark by Hoebel (1941):

Though infanticide is casually accepted, according to reports on the Eskimos, senilicide gives rise to greater emotional conflict.

Not infrequently the aged one has to insist on his 'right' to be killed. (p. 671)

The elderly thus welcomed the advantage which their absence from the community had for the community itself. The notion of their absence from the community was not forced upon them but willingly accepted as part of a reality brought about by the natural environment and the whole community's dependence on limited resources. This is in stark contrast to the modern notion that all human life must be prolonged as far as possible.

These perspectives, taken from the primitive Eskimos' attitudes are included not for the sake of moral judgement, but for the sake of showing how the environment can fundamentally influence the internalising of values of a specific community. In the Eskimo community the environment (as vindex and iudex) had the last say while in modern thought humanity does.

\section{Assyrian attitude towards fruit trees portrayed in Iconographic Sources}

The military tactics of the Assyrians are well attested for. Iconographic sources in the British Museum affirm that fruit trees were left standing during siege and even thereafter, as is shown on the gypsum wall panel relief portraying prisoners from Lachish (Figure 1). Although the siege and destruction of the city was completed, the vines, fig trees and olives clearly portrayed in the background were left intact (British Museum n.d.).

Hasel $(2008: 76,80)$ also states that the situation depicted in the reliefs is not an exception and that only in a few instances are trees shown to be cut down. What is of further importance is that on a relief in the throne room of Ashurbanipal the enemies lie beheaded and strewn on the battlefield with fruit trees and shrubs left standing. Not all people were killed while some are shown as deportees left alive with a purpose.

\section{Conclusion}

The Geneva Conventions provide direct protection of the environment in times of war. However, no such protection for the natural environment exists during day to day activities of the human community resulting in destruction to the extent that it can be classified as 'widespread', 'long-term' and 'severe'. This can be ascribed to the unchecked increase of the world's human population encroaching more and more on nature. The modern human assumption that all human life is of equal value and in general superior to nature, is contradicted by Deuteronomy 20, the maximalist approach of bal tashchit, the practicality of primitive Eskimo judgment as well as the Assyrians of the Ancient Near East. In all these thought systems the dependence of humans on nature in 


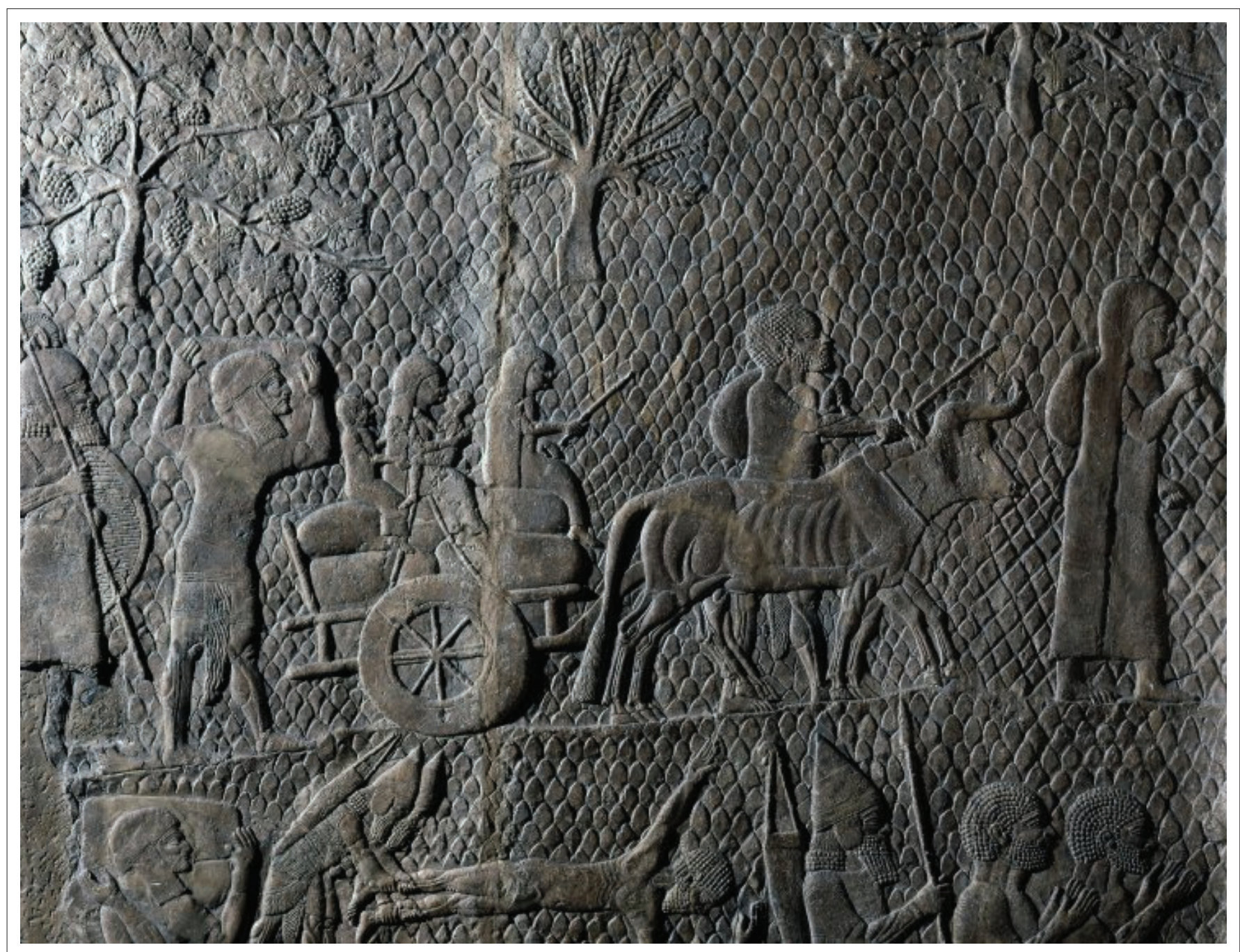

Source: The British museum, n.d., Gypsum wall panel relief: showing prisoners from Lachish. A procession of prisoners moves through rocky landscape with vines, fig trees and olives in background, viewed 09 October 2015, from http://www.britishmuseum.org/research/collection_online/collection_object_details/collection_image_gallery.aspx?partid=1\&assetid=785644001\&objectid=366874 FIGURE 1: Wall panel relief portraying prisoners from Lachish.

order to ensure the continuation of human existence was acknowledged, and that is something which we can learn from these societies who were not so 'removed' from the natural environment as modern society.

It is thus not sensible that jus cogens as iudex should apply only to the right of humans, for in doing so the balance needed in nature for humankind to exist will be upset and neither nature nor humans will thrive.

Human existence should therefore not per se be valued above that of nature, nor should any endeavour be made to prolong human life indefinitely. The rationale behind this being the fact that God, as the giver of life, commanded the taking thereof in order to ascertain future existence for both man and nature. It must be clearly stated that in no sense any propagation is made in this article for the taking of human life. What is called for is a paradigm shift in the minds of individuals. Our vindex should be that not mere existence but also functionality and potentiality should form part of establishing our philosophy on the right to life.
A new set of moral rules (as iudex) should therefore be internalised challenging humankind's perceived right to prolonged life which is not viable because it comes at the expense of nature and humanity at large.

\section{Acknowledgements Competing interests}

The author declares that he has no financial or personal relationships which may have inappropriately influenced him in writing this article.

\section{References}

Barr, J., 2003, 'A puzzle in Deuteronomy', in C. Exum \& H.G.M. Williamson (eds.) Reading from left to right - Essays on the Hebrew Bible in honour of David J.A. Clines, pp. 13-24, T\&T Clark, London.

Barrett, R., 2009, Disloyalty and destruction: Religion and politics in Deuteronomy and the modern world, T \& T Clark, New York.

Benjamin, D.C., 1983, Deuteronomy and city life: A form criticism of texts with the word city ('ir) in Deuteronomy 4: 41-26: 19, University Press of America, New York.

Brueggemann, W., 2001, Deuteronomy, Abingdon Press, Nashville, TN.

Doughty, S., 2013, 'Ageing Britain: Half of our children will live to be 103 and the first person to reach 150 has already been born', viewed 21 December 2015, from http://www.dailymail.co.uk/news/article-2293015/Ageing-Britain-Half-childrenlive-103-number-85s-double-2030.html 
Gormley, 1985, 'The right to life and the rule of non-derogability: Peremtory norms of jus cogens', in B.G. Ramcharan (ed.), The right to life in international law, pp. 120-159, Martinus Nijhoff, Dordrecht.

Gray, L., 2013, 'David Attenborough - Humans are plague on earth', The Telegraph viewed 13 November 2015, from http://www.telegraph.co.uk/news/earth/ earthnews/9815862/Humans-are-plague-on-Earth-Attenborough.html

Hasel, M.G., 2008, 'Assyrian military practices and Deuteronomy's laws of warfare', in B.E. Kelle \& F.R. Ames (eds.), Writing and reading war: Rhetoric, gender and ethics in biblical and modern contexts, pp. 67-81, Society of Biblical literature, Atlanta.

Hoebel, E.A., 1941, 'Law-ways of the primitive Eskimos', Journal of Criminal Law and Criminology (1931-1951), 663-683.

International Committee of the Red Cross (ICRC), 1977, Protocol additional to the Geneva Conventions of 12 August 1949, and relating to the protection of victims of international armed conflicts (Protocol I), viewed 12 January 2016, from of international armed conflicts

Jonker, L., 1997, 'קרא', in W. VanGemeren (ed.), New international dictionary of Old Testament theology \& exegesis, vol. 3, pp. 971-973 Zondervan, Grand Rapids, MI.

Lundbom, J.R., 2013, Deuteronomy: A commentary, Eerdmans, Grand Rapids, MI.

Milman, O., 2014, 'Full scale of plastic in the world's oceans revealed for first time', The Guardian, viewed 11 January 2016, from http://www.theguardian.com/ environment/2014/dec/10/full-scale-plastic-worlds-oceans-revealed-first-timepollution

Nelson, R.D., 2002, Deuteronomy: A commentary, Westminister John Knox, London.

Ramcharan, B.G., 1985, The right to life in international law, Martinus Nijhoff Publishers, Dordrecht.

Rofé, A., 2002, Deuteronomy: Issues and interpretations, T \& T Clark, London.
Schwartz, E., 1997, 'Bal Taschit', Environmental Ethics 19(4), 355-374. http://dx.doi. org/10.5840/enviroethics19971943

The British museum, n.d., Gypsum wall panel relief: showing prisoners from Lachish. A procession of prisoners moves through rocky landscape with vines, fig trees and olives in background, viewed 09 October 2015, from http://www.britishmuseum. org/research/collection_online/collection_object_details/collection_image gallery. aspx? partid $=1 \&$ assetid $=785644001 \&$ objectid $=366874$

Thomas, C., 2013, 'Advancing the legal protection of the environment in relation to armed conflict: Protocol I's threshold of impermissible environmental damage and alternatives', Nordic Journal of International Law 82(1), 83-101. http://dx.doi. org/10.1163/15718107-08201005

Verbaan, P., 2011, Bankbiljetten op de A2', Theoblogie, viewed 18 Mei 2016, from http://www.boekencentrum.nl/weblog.php?blogld=3\&blogPostld=985

Wenham, G.J., 2003, Exploring the Old Testament: The Pentateuch, Society for Promoting Christian Knowledge, London.

Wolff, A., 2011, 'A closer examination of Deuteronomy 20:19-20', Jewish Bible Quarterly 39(3), 143-151.

Wolff, K.A., 2009, Bal Tashchit: The Jewish prohibition against needless destruction Faculty of Medicine/Leiden University Medical Center (LUMC), Leiden University.

World Wildlife Fund (WWF), 2014, Living planet report 2014, World Wildlife Fund.

Wright, J., 2015, 'Urbicide: The ritualized killing of cities in the ancient Near East', in $\mathrm{S}$. M. Olyan (ed.), Ritual violence in the Hebrew Bible: New perspectives, pp. 147-166, Oxford University Press, Oxford.

Wright, J.L., 2008, 'Warfare and wanton destruction: A reexamination of Deuteronomy 20:19-20 in relation to ancient siegecraft', Journal of Biblical Literature 127(3), 423-458.

Zehnder, M., 2013, 'The annihilation of the Canaanites,' in M. Zehnder \& H. Hagelia (eds.), Encountering violence in the Bible, Sheffield Phoenix, Sheffield. 